\title{
WNT Family Gene
}

National Cancer Institute

\section{Source}

National Cancer Institute. WNT Family Gene. NCI Thesaurus. Code C20100.

WNT Family Genes encode secreted structurally related signaling WNT Family Proteins, implicated in oncogenesis and in several developmental processes, including regulation of cell fate and embryonic patterning. ( $\mathrm{NCl})$ 